\title{
Maternally Derived Immunoglobulin Light Chain Is Present in the Fetal Mammalian CNS
}

\author{
Joshua A. Weiner ${ }^{1}$ and Jerold Chun ${ }^{2}$ \\ ${ }^{1}$ Neurosciences Graduate Program and ${ }^{2}$ Neurosciences and Biomedical Sciences Graduate Programs, Department of \\ Pharmacology, School of Medicine, University of California, San Diego, La Jolla, California 92093-0636
}

Toward identifying molecules involved in cell-cell interactions during cerebral cortical development, we have investigated the nature of immunoglobulin-like immunoreactivity (lg-ir) in the murine cortex. Immunohistochemistry using several antisera recognizing IgG revealed intense immunoreactivity in the subplate and marginal zone of embryonic day 16 cortex, as well as in the hindbrain and spinal cord, particularly within ventral fiber tracts. In three independently derived mouse strains lacking the recombination activating genes RAG-1 or RAG-2, which are essential for Ig production, Ig-ir was absent from the fetal CNS. Western blot analyses of wild-type brains from embryonic day 12 through birth identified a $25 \mathrm{kDa}$ protein that co-migrated with Ig light chain and was absent from RAG-1 or RAG-2 -/- brain samples. This result could be replicated with an antiserum specific for lg $\kappa$ light chain, but not with antisera specific for lg $\gamma$ or $\mu$ heavy chain. No lg-ir was detected in the brains of RAG-1 $+/-$ embryos carried by a $-/$ - female, suggesting a maternal source of the immunoreactive molecule. In confirmation of this, Ig-ir could be partially reproduced by intraperitoneal injection of pregnant RAG-1 -/- females with normal mouse serum. We conclude that maternally derived Ig light chain is present in the fetal murine CNS. This may represent a novel maternal contribution to fetal neural development and implicates Ig molecules as potential mediators of cortical developmental events.

Key words: subplate; cortex; immunoglobulin; RAG; development; light chain
During fetal development, the mammalian cerebral cortex consists of transient histological zones distinct from those of the adult (Boulder Committee, 1970). Two of these, the subplate and marginal zone, contain the earliest-generated neurons of the cortex (Luskin and Shatz, 1985; Chun et al., 1987), which are largely eliminated in the early postnatal period (Chun and Shatz, 1989; Woo et al., 1991; Wood et al., 1992). Afferent fibers from the thalamus, which will innervate the cortical plate, arrive early, before their target neurons have migrated, and "wait" in the subplate (Luskin and Shatz, 1985). Their correct cortical targeting depends on cell-cell interactions within the subplate, which include transient synapses and contact with extracellular matrix components (Stewart and Pearlman, 1987; Chun and Shatz, 1988a,b; Ghosh et al., 1990).

Members of the immunoglobulin superfamily (IgSF) likely have roles in such developmental events, although gene knock-out studies have not revealed clear cortical phenotypes (Tomasiewicz et al., 1993; Cremer et al., 1994; Müller and Kypta, 1995). Two IgSF members, N-CAM and L1, are known to be expressed within the subplate (Fushiki and Schachner, 1986; Chung et al., 1991). Actual immunoglobulin (Ig) molecules may also be present, based on the observation of IgG-like immunoreactivity (Ig-ir) in the fetal subplate and marginal zone of the rat (Fairén et al., 1992).

\footnotetext{
Received Feb. 10, 1997; accepted Feb. 19, 1997.

This work was supported by the National Institute of Mental Health and the James H. Chun Memorial Fund (J.C.) and by a National Science Foundation Graduate Fellowship (J.A.W.). We thank Ms. Carol Akita for expert histological assistance and Dr. David Schatz, Ms. Anne Blaschke, and Dr. Kristina Staley for critically reading this manuscript.

Correspondence should be addressed to Dr. Jerold Chun, Department of Pharmacology, School of Medicine, University of California, San Diego, 9500 Gilman Drive, La Jolla, CA 92093-0636.

Copyright (C) 1997 Society for Neuroscience $0270-6474 / 97 / 173148-09 \$ 05.00 / 0$
}

The identity of the immunoreactive molecule(s), however, is unknown.

Igs consist of two heavy and two light chains. Both heavy and light chains contain variable regions with antigen binding domains that are encoded by constituent gene segments, assembled through somatic DNA rearrangement referred to as $\mathrm{V}(\mathrm{D}) \mathrm{J}$ recombination (Tonegawa, 1983; Schatz et al., 1992). V(D)J recombination and, thus, B-cell production of Igs depend on the immunological recombinase encoded in part by the recombination-activating genes RAG-1 and RAG-2 (Schatz et al., 1992; McBlane et al., 1995). In addition to the variable regions, both heavy and light chains contain constant regions that do not undergo V(D)J recombination. Five constant region isoforms define five Ig subtypes: $\gamma(\operatorname{IgG}), \mu(\operatorname{IgM}), \alpha$ $(\operatorname{Ig} \mathrm{A}), \delta(\operatorname{IgD})$, and $\epsilon(\mathrm{IgE})$. Light chain constant regions are of two types, which appear in all Ig classes: $\kappa$, which comprises $95 \%$ of the murine light chain pool (Chen et al., 1993), and $\lambda$. Although autonomous Ig production in the mouse begins postnatally (Appleby and Catty, 1983; Cooper and Nisbet-Brown, 1993), IgG is placentally transferred from mother to fetus during gestation (Appleby and Catty, 1983; Parr and Parr, 1985).

Here, we have investigated the identity of the molecule responsible for Ig-ir in the developing murine CNS. Using immunohistochemistry and Western blot analyses on RAG-1 and RAG-2 wild-type and mutant mice, we show that the molecule comigrates with Ig light chain, is dependent on RAG-1 and RAG-2, is maternally derived, and can be reconstituted in RAG -/- mice by normal serum, identifying the molecule as Ig light chain.

\section{MATERIALS AND METHODS}

Animals. Embryos were obtained from timed-pregnant female mice, with morning of vaginal plug designated day 0 . On embryonic day 12 (E12), $\mathrm{E} 14$, or E16, pregnant mice were anesthetized via intraperitoneal injection with $0.8 \mathrm{ml}$ of $2.5 \%$ (v/v) Avertin. Embryos were removed and either prepared for immunohistochemistry or dissected for protein samples. 
Table 1. Types and ages of animals analyzed

\begin{tabular}{lllc} 
& & \multicolumn{2}{c}{ Number of animals analyzed } \\
\cline { 3 - 4 } Animal type & Age & $\begin{array}{l}\text { Immunohisto- } \\
\text { chemistry }\end{array}$ & $\begin{array}{c}\text { Western } \\
\text { blot }\end{array}$ \\
\hline Wild type $^{a}$ & E12 & - & 4 \\
& E14 & 2 & 4 \\
& E16 & 18 & 14 \\
RAG-1 $-/{ }^{b}$ & P1 & 5 & 6 \\
RAG-2 $-/-$ & E16 & 4 & 5 \\
RAG-1 $-/-$ & P1 & 3 & 4 \\
treated with normal & E16 & 4 & 6 \\
mouse serum & E16 & 4 & 5 \\
RAG-1 $+/-$ & & & \\
& & & 3 \\
& E16 & 2 & 51
\end{tabular}

${ }^{a}$ Includes animals from three different strains: Balb/c, 129/Sv, and a C57BL/6-129 background strain matched to one of the RAG-1 $-/-$ strains used. All strains gave similar results; animals shown are from the matched-background strain.

${ }^{b}$ Includes animals from two independently derived RAG-1 -/- strains (Mombaerts et al., 1992; Spanopoulou et al., 1994). Both strains gave similar results; animals shown correspond to the mutation described by Mombaerts et al. (1992) and were obtained from Jackson Laboratories (Bar Harbor, ME).

Methods were similar for postnatal animals. Some pregnant RAG-1 -/animals were injected intraperitoneally with $0.9 \mathrm{ml}$ of normal mouse serum (Sigma, St. Louis, MO) at E13.5. RAG-1 -/- mice and their matched background strain (C57BL/6-129) were obtained from Jackson Laboratories (Bar Harbor, ME); a second, independently derived RAG-1 $-/-$ strain was obtained from Drs. E. Spanopoulou and D. Baltimore (MIT). RAG-2 - /- mice were obtained from Taconic Farms (Germantown, NY). The ages, numbers, and types of animals used in these studies are summarized in Table 1.

Tissue preparation for histology. Embryos and neonates were either perfusion- or immersion-fixed in Millonig's fixative (4\% paraformaldehyde, $0.1 \mathrm{M}$ monobasic sodium phosphate, $\mathrm{pH}$ 7.4). Whole embryos or heads were post-fixed overnight in the same fixative, followed by immersion in 6\% sucrose in PBS overnight. Tissue was embedded in Tissue Tek freezing compound (Miles, Elkhart, IN) and snap-frozen in Histofreeze (Fisher Scientific, Pittsburgh, PA) on dry ice. Sagittal cryostat sections (20- $\mu$ m-thick) were mounted onto double gelatin-subbed glass slides. Slides were used immediately for immunohistochemistry or stored desiccated at $-20^{\circ} \mathrm{C}$.

Immunohistochemistry. The primary antisera and dilutions used in immunohistochemistry and Western blot analyses are listed in Table 2. Cryostat sections were incubated in a humidified chamber at room temperature with blocking solution [5\% BSA, $0.6 \%(\mathrm{w} / \mathrm{v})$ Triton X-100 in PBS] for $1 \mathrm{hr}$ or longer, followed by overnight incubation with the various antisera diluted in blocking solution. Slides were washed in multiple changes of PBS, incubated for $1 \mathrm{hr}$ with secondary antiserum (biotinylated anti-rabbit IgG at 1:200 in PBS; Vector Laboratories, Burlingame, $\mathrm{CA}$ ), and treated with $0.3 \% \mathrm{H}_{2} \mathrm{O}_{2}$ in methanol to inactivate endogenous peroxidase activity (for slides incubated with biotinylated primary goat or horse antiserum, a secondary antiserum step was not necessary). Visualization used ABC-HRP (ABC kit, Vector) and $0.5 \mathrm{mg} / \mathrm{ml} \mathrm{DAB} \mathrm{(Sigma)}$ with $0.01 \% \mathrm{H}_{2} \mathrm{O}_{2}$ in TBS. Adjacent sections were stained with $0.5 \%(\mathrm{w} / \mathrm{v})$ cresyl violet. Control sections were incubated with secondary antiserum in the absence of primary antiserum incubation or with primary antiserum (anti-IgG) preincubated with a 2.5 -fold excess of purified mouse IgG (Sigma) for $30 \mathrm{~min}$ at room temperature or at $37^{\circ} \mathrm{C}$; no immunostaining was observed. Slides were dehydrated in graded ethanols and mounted in toluene-based resin (Cytoseal 60, Stephens Scientific, Riverdale, NJ) for light microscopy.

Western blotting. Techniques were essentially as described previously (Chun and Jaenisch, 1996). Mouse brains were removed rapidly from the cranium, added to an equal volume of $2 \times$ sample buffer $[0.125 \mathrm{M}$ Tris, $\mathrm{pH} 6.8,4 \%$ SDS, $20 \%(\mathrm{v} / \mathrm{v})$ glycerol, $10 \%(\mathrm{v} / \mathrm{v}) \beta$-mercaptoethanol, $0.02 \%$ bromophenol blue] and homogenized in a glass Dounce homogenizer. Samples were boiled for $10 \mathrm{~min}$ before use and stored at $-20^{\circ} \mathrm{C}$.
Adult spleen, WEHI 231, and mouse IgG samples were similarly prepared. Protein samples $(\sim 20-30 \mu \mathrm{g})$ were separated by discontinuous SDS-PAGE using 11 or $15 \%$ separating gels. For purified mouse IgG preparation (Sigma), $25 \mathrm{ng}$ of protein was loaded. Proteins were transferred to PVDF membranes (Immobilon P, Millipore, Bedford, MA) and blots blocked as suggested by the manufacturer. After overnight incubation in primary antisera diluted in $1 \%$ BSA and $0.05 \%$ Tween 20 in TBS, blots were washed in $0.1 \%$ BSA in TBS, incubated with secondary antiserum (biotinylated anti-rabbit IgG at 1:1000; Vector) for $45 \mathrm{~min}$, and visualized as above. Control blots for which primary antiserum was omitted or (for anti-IgG) preincubated with fivefold excess mouse IgG eliminated or nearly eliminated immunoreactive bands, respectively.

Southern blotting. Techniques used were essentially as described (Chun and Jaenisch, 1996). To confirm the genotype of examined wild-type, RAG-1 - / , and RAG- $2-/-$ tissues, the tail regions of representative embryos were removed and incubated overnight at $50^{\circ} \mathrm{C}$ in digestion buffer $(0.075 \mathrm{M} \mathrm{NaCl}, 0.025$ м EDTA, $0.01 \mathrm{~m}$ Tris, pH 8.0, $1 \%$ SDS, 0.4 $\mathrm{mg} / \mathrm{ml}$ proteinase K). Samples were extracted with phenol/chloroform and the genomic DNA ethanol precipitated, collected by spooling, dissolved in TE (10 mM Tris, $1 \mathrm{~mm}$ EDTA, $\mathrm{pH} 8.0$ ), and digested with $B a m \mathrm{HI}$ and $\mathrm{Nco}$ I (for RAG-1) or EcoRI and XbaI (for RAG-2) for fractionation by agarose gel electrophoresis. Gels were Southern blotted using standard methods (Ausubel et al., 1994) and hybridized overnight at $65^{\circ} \mathrm{C}$ with the appropriate ${ }^{32} \mathrm{P}$-labeled probe $\left(1-2 \times 10^{6} \mathrm{cpm} / \mathrm{ml}\right)(\mathrm{Mom}-$ baerts et al., 1992; Shinkai et al., 1992).

\section{RESULTS}

\section{Ig-ir is present in the fetal CNS}

Ig-ir was first examined in the developing cortex of wild-type mice at E16. The subplate and the upper intermediate and marginal zones were immunostained for IgG throughout the length of the cortex (Fig. 1A). Anteriorly, the immunostained area extended ventrally, and posteriorly included the hippocampal primordium. The intervening cortical plate, as well as the ventricular zone, was unstained. This pattern of immunostaining was similar to that seen on an adjacent section stained for synapsin I (Fig. 1C), which has been shown to be present in the subplate and marginal zone (Chun and Shatz, 1988b). Fiber tracts, which appeared to extend both to and from the cortex, were also Ig-immunoreactive (Fig. $1 D)$. Ig-ir was similarly localized to regions containing fiber tracts in the ventral portion of the hindbrain and spinal cord at E16 (Fig. $2 A$ ). No immunostaining was evident in sections for which primary antisera were omitted or were replaced by an anti- $\mu$ heavy chain (IgM) antiserum; further, preadsorption of primary anti$\mathrm{IgG}$ antiserum with a 2.5 -fold excess of mouse $\mathrm{IgG}$ completely abolished immunostaining (data not shown).

\section{Ig-ir is RAG-1- and RAG-2-dependent}

To determine the RAG-dependence of the CNS Ig-ir, embryos of mice homozygous for a deletion of either RAG-1 or RAG-2, which have no Igs (Mombaerts et al., 1992; Shinkai et al., 1992; Spanopoulou et al., 1994), were examined by immunohistochemistry. Ig-ir was absent from all RAG-1 -/- cortical areas (Fig. $3 A$ ), as it was from the rest of the CNS and the embryo (data not shown). An identical result was obtained using RAG-2 -/embryos (Fig. 3D). For both mutations, Ig-ir was absent, despite qualitatively normal cortical morphology and normal immunoreactivity for synapsin I (Fig. $3 B, C, E$ ). Genotypes of all wild-type and RAG $-/-$ animals were confirmed by Southern blot (e.g., Fig. $3 F$ ) ; because of introduction of another NcoI site by integration of the RAG-1 knock-out vector (Mombaerts et al., 1992) and another EcoRI site by integration of the RAG-2 knock-out vector (Shinkai et al., 1992), -/- animals can be detected by blotting genomic DNA cut with the appropriate restriction enzyme. 
Table 2. Antisera and dilutions used

\begin{tabular}{lccc} 
& Dilution & & \\
\cline { 2 - 3 } Antiserum & Immunohistochemistry & Western blot & Source \\
\hline $\begin{array}{l}\text { Rabbit anti-mouse IgG }(\mathrm{H}+\mathrm{L})^{a} \\
\begin{array}{l}\text { Horse anti-mouse IgG }(\mathrm{H}+\mathrm{L}), \\
\quad \text { biotinylated }\end{array}\end{array}$ & $1: 400$ & $1: 5000$ & Jackson ImmunoResearch, West Grove, PA \\
$\begin{array}{l}\text { Horse anti-mouse Ig } \gamma \text { heavy } \\
\quad \text { chain, biotinylated }\end{array}$ & $1: 400$ & $1: 2000$ & Vector Laboratories, Burlingame, CA \\
$\begin{array}{l}\text { Goat anti-mouse Ig } \mu \text { heavy } \\
\quad \text { chain, biotinylated }\end{array}$ & $1: 400$ & $1: 2000$ & Vector Laboratories \\
$\begin{array}{l}\text { Rabbit anti-mouse Ig } \kappa \text { light chain } \\
\text { Rabbit anti-synapsin I }\end{array}$ & $1: 2000$ & $1: 2000$ & Vector Laboratories \\
\end{tabular}

${ }^{a}$ Recognizes both heavy (H) and light (L) chains of IgG.

\section{The immunoreactive molecule in the CNS resembles Ig light chain}

To determine the identity of the immunostained molecule, Western blot analyses were performed using the same anti-IgG antisera used for immunohistochemistry, recognizing both heavy and light chains of IgG. Control Western blots (Fig. 4A) confirmed that the anti-IgG antisera did indeed recognize the expected mouse heavy and light chain Ig proteins; in both a purified mouse IgG preparation and a protein sample from adult spleen, bands of $\sim 55 \mathrm{kDa}$, corresponding to $\gamma$ heavy chain, and of $\sim 25 \mathrm{kDa}$, corresponding to the common $\kappa$ or $\lambda$ light chains, were detected. WEHI 231, a mature B-cell line expressing $\operatorname{IgM}$ containing $\kappa$ light chain, produced only a light chain immunoreactive band, as expected for these antisera.

Analysis of wild-type brain samples from E12 through postnatal day 1 (P1) using anti-IgG antisera identified a single band that co-migrated with Ig light chain at $\sim 25 \mathrm{kDa}$ (Fig. $4 B$ ). The intensity of the immunoreactive band increased between E12 and E14, peaked at E16, and was near the limit of detection by P1. No band corresponding in size to $\gamma$ heavy chain could be detected in these or any other wild-type brain sample examined, despite internal positive controls demonstrating the ability of the assay to detect $\gamma$ heavy chain (see Fig. $4 A, B$, far left lane). Further, antisera specific for $\gamma$ or $\mu$ heavy chain detected no specific immunoreactive bands (data not shown).

Consistent with the immunohistochemistry results, the $25 \mathrm{kDa}$ light chain-like band was absent from brain protein extracts of E16 RAG-1 -/- or RAG-2 -/- mice (Fig. 4B). No other bands were detected in these samples nor in P1 brain samples from two independently derived RAG- $1-/-$ mutants (denoted $a$ and $b$ ). Western blots of the same set of wild-type and RAG -/- brain samples probed with an antiserum specifically recognizing mouse $\kappa$ light chain produced results identical to those obtained with the anti-IgG antisera (data not shown). In situ hybridization experiments using a $\kappa$ light chain constant region riboprobe, however, did not detect any transcript expression in wild-type fetal brain (data not shown).

\section{Expression of the light chain-like protein depends on maternal RAG-1}

The absence of Ig-ir in RAG -/- embryos could be attributable to the lack of RAG expression either in the embryos or in the mothers, who were $-/-$ as well. To distinguish between these two possibilities, RAG-1 -/- females were crossed with wild-type males. The resulting heterozygote embryos carried by these females could not have received any maternal RAG-dependent proteins such as Igs; however, embryos did have one functional copy of the RAG-1 gene, which could allow them to produce RAG-dependent molecules autonomously. Western blot analysis of E16 RAG-1 +/- brain samples did not reveal any immunoreactive bands (Fig. 5A, far right lane). Immunohistochemistry experiments on these heterozygotes demonstrated a similar absence of any Ig-ir (data not shown).

\section{Light chain-like protein can be reconstituted in the fetal RAG-1 -/-CNS}

To confirm that the light chain-like molecule seen in the fetal CNS was maternally derived, pregnant RAG-1 -/- mice were injected intraperitoneally at E13.5 with normal mouse serum containing Igs, which are absent from RAG $-/-$ mice (Mombaerts et al., 1992; Shinkai et al., 1992). Embryos were analyzed by immunohistochemistry and Western blot at E16. Injection of pregnant RAG-1 -/- females with normal mouse serum resulted in reconstitution of the wild-type $25 \mathrm{kDa}$ band in Western blot analyses of fetal RAG-1 -/- brain (Fig. 5A). A partial reconstitution of the wild-type pattern of Ig-ir was also observed when these serumtreated RAG-1 -/- embryos were examined by immunohistochemistry. Ig-ir was apparent in the cerebral wall (Fig. 5B). A similar degree of reconstitution of wild-type Ig-ir was also observed in the hindbrain and spinal cord (Fig. 5C).

\section{DISCUSSION}

\section{The Ig-ir protein in the fetal CNS is Ig light chain}

The molecule responsible for CNS Ig-ir is Ig light chain, based on convergent data. First, immunoreactivity in the cortex and other regions of the developing CNS was replicated using multiple antisera that recognize light chains of IgG. Second, these same antisera detect a single protein species in wild-type fetal brain that co-migrates with Ig light chain at $25 \mathrm{kDa}$ on Western blots. This $25 \mathrm{kDa}$ protein was also detected by an antiserum specific for Ig $\kappa$ light chain, but not by antisera specific for Ig $\gamma$ or $\mu$ heavy chain. Third, both this $25 \mathrm{kDa}$ protein and CNS Ig-ir in situ required RAG-1 and RAG-2; the only molecules known to require these two genes for their synthesis are Igs and T-cell receptors (Schatz et al., 1992). Fourth, this $25 \mathrm{kDa}$ protein and Ig-ir in situ is dependent on maternal, but not fetal, RAG-1 expression. Fifth, maternal delivery of normal mouse serum in RAG-1 $-/-$ mice reconstitutes the $25 \mathrm{kDa}$ protein in RAG- $1-/-$ fetal CNS. Thus, a $25 \mathrm{kDa}$, Ig-immunoreactive protein that requires both RAG-1 and RAG-2 is maternally derived and is present in normal serum meets criteria for identification as Ig light chain.

IgG and small amounts of IgM are placentally transferred from 

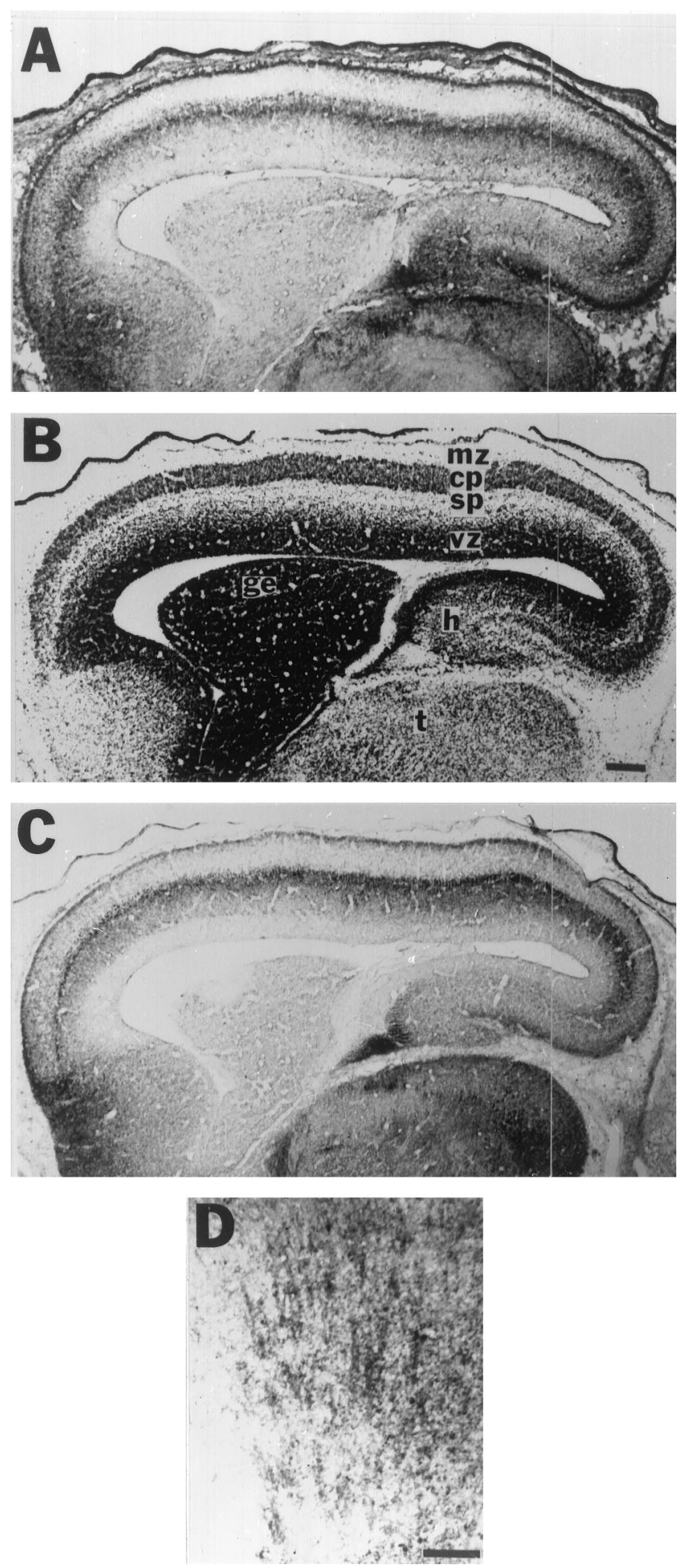

Figure 1. Ig-ir is present in wild-type fetal cerebral cortex. Adjacent sagittal cryostat sections through an E16 wild-type cortex were stained with anti-mouse $\operatorname{IgG}$ (heavy and light chain) antiserum $(A, D)$, cresyl violet $(B)$, or anti-synapsin I antiserum $(C)$. Ig-ir is present in the subplate $(s p)$ and marginal zone $(\mathrm{mz})$ of the cortex, continuing posteriorly into the hippocampal primordium $(h)(A)$. The ventricular zone $(v z)$ and cortical plate $(c p)$ are unstained. The superior portion of the thalamus $(t)$ also exhibits Ig-ir. $B$, Cresyl violet staining reveals cell body location and delineates fetal cortical zones. $C$, Synapsin I immunoreactivity, known to mother to fetus during gestation in the mouse (Appleby and Catty, 1983; Parr and Parr, 1985), although localization to the CNS had not been examined previously. Surprisingly, our Western blot analyses of brain protein extracts did not detect a band corresponding in size to Ig heavy chain (at least of $\gamma$ or $\mu$ isotypes); only a $25 \mathrm{kDa}$ light chain band is detected. There are two possible explanations for this result. First, IgG reaches the fetal CNS, but the heavy chain is selectively degraded, whereas the light chain is retained. This seems unlikely, because heavy chain degradation products were never detected. It remains possible that there is a small amount of Ig heavy chain below the limit of detection on Western blots; however, maximizing the amount of brain protein sample loaded did not reveal any heavy chain-like bands (data not shown) despite heavy chains being clearly detectable in protein samples from spleen and in a purified IgG preparation (Fig. 4A).

A second, more likely explanation is that free light chain reaches the fetal CNS. Classical immunological studies have determined that stimulated B-cells can release significant amounts of free light chain, estimated to be up to $10-20 \%$ of the total $\mathrm{Ig}$ production (Shapiro et al., 1966; Sølling, 1981). Consistent with this, free light chains are found in normal serum (Berggård and Edelman, 1963; Sølling, 1981). Thus, free light chain in the CNS could be derived from its presence in normal mouse serum. Intriguingly, there is already a known connection between free light chain and the CNS; patients with multiple sclerosis (Rudick et al., 1985) and HIV infection (Elovaara et al., 1991) have high amounts of free light chain in their CSF compared with controls.

\section{Ig light chain is localized to the subplate and marginal zone within the fetal cerebral cortex}

The Ig light chain immunostaining was confined to the subplate and marginal zones within the embryonic cortex. Several other plasma proteins have been observed in the developing mammalian cortex (Møllgard and Jacobsen, 1984; Møllgard et al., 1988; Dziegielewska et al., 1993); however, none of them replicate the Ig immunostaining pattern seen in the wild-type embryos. Plasma proteins examined, such as albumin and transferrin (Møllgard and Jacobsen, 1984), are generally detected by immunohistochemistry in the ventricular zone and/or diffusely in the cortical plate. Furthermore, some plasma proteins are synthesized by the cells of the cortex (Møllgard et al., 1988; Dziegielewska et al., 1993). This is clearly not the case for Ig light chain, because both Northern blot and in situ hybridization analyses using a $\kappa$ light chain constant region probe failed to detect any transcript expression in wild-type fetal brain (data not shown). The characteristic localization of Ig light chain in the fetal cortex distinguishes it from other embryonic plasma proteins.

The Ig-ir in the cortices of RAG-1 -/- mice treated with normal serum was less distinctly localized to the subplate and marginal zone. This may be explained by the fact that the reconstitution experiments used a single injection with serum at E13.5, instead of the potentially continuous maternal serum exposure in wild-type mice. With the development of the blood-brain barrier between E13 and E16 (Risau et al., 1986), continuous serum exposure may be necessary to obtain the pattern and intensity of

label the subplate and marginal zone, is similar in its localization to Ig-ir. $D$, In more lateral sagittal sections, fibers radiating to and from the cortex are Ig-immunoreactive. ge, Ganglionic eminence. Scale bars: $A-C, 200$ $\mu \mathrm{m} ; D, 100 \mu \mathrm{m} . A-C$, Left indicates rostral; top, dorsal. 

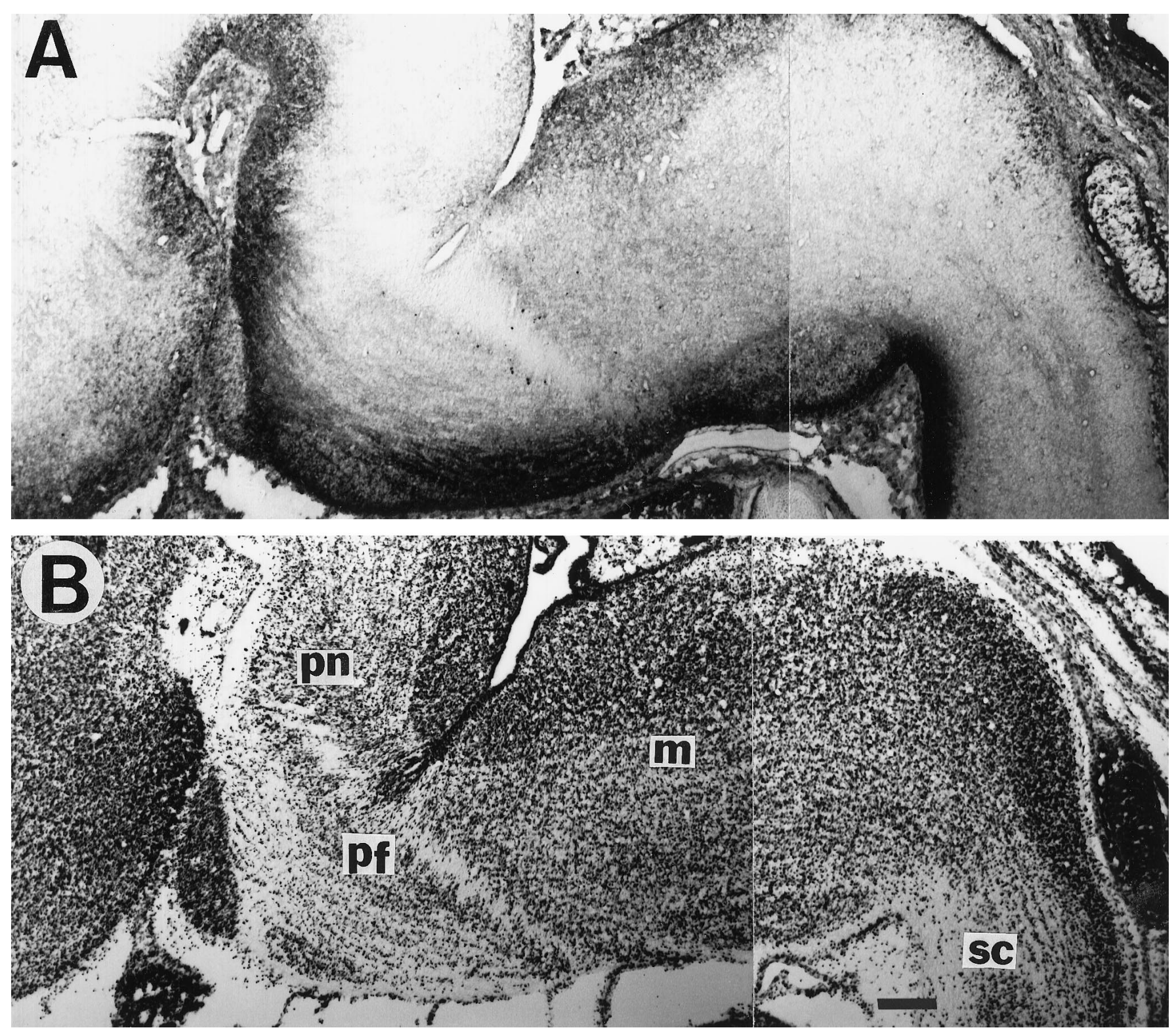

Figure 2. Ig-ir is present in wild-type fetal hindbrain and spinal cord. $A$, In a sagittal section through the hindbrain and spinal cord at E16, stained with anti-IgG antiserum, Ig-ir appears to be localized to fiber tracts in ventral regions. $B$, An adjacent cresyl violet-stained section shows that Ig-immunoreactive regions are cell-sparse, indicating the presence of fiber tracts. $p n$, Pons; $p f$, pontine flexure; $m$, medulla; $s c$, spinal cord. Scale bar, $200 \mu \mathrm{m}$.

immunoreactivity seen in wild-type cortex. Despite this less distinct localization, the Ig-ir reconstituted by serum exposure was always associated with only the $25 \mathrm{kDa}$ light chain band by Western blot analysis.

Ig-ir has been observed previously in the postnatal cat subplate, associated with a $56 \mathrm{kDa}$ molecule. This molecule was first detected using monoclonal antibody SP1, derived from subplate antigens (Naegele et al., 1991), which appears to have overlapping recognition properties with anti-cat IgG antiserum (Henschel and Wahle, 1994; Dunn et al., 1995). The molecule, consistent in size and in some peptide sequence with IgG heavy chain, cannot be detected in the fetal cat cortex (Naegele et al., 1991; Henschel and Wahle, 1994); this, along with differences in antigen size, species, and antisera used, makes its relationship to Ig light chain detected in the mouse unclear. However, we note that identification strategies based on biochemically isolating Ig molecules from wild-type CNS (Henschel and Wahle, 1994), regardless of species, are complicated by unavoidable contamination from high levels of Ig present in serum and locally produced by B-cells.

In contrast to previous studies, we have made use of three independently derived mutations producing Ig-null phenotypes (two RAG-1 -/- and one RAG-2 -/-). This genetic approach has allowed us to (1) determine the identity of the molecule based on its dependence on RAGs, in conjunction with its antigenic properties and size, and (2) discriminate between maternal and fetal sources of the CNS molecule through genetic crosses and normal serum reconstitution experiments in RAG-1 -/- mice. Although the possibility of species differences in CNS Ig molecules requires additional study, we conclude that maternally derived light chain is the molecule primarily responsible for the observed Ig-ir in the fetal mouse. 

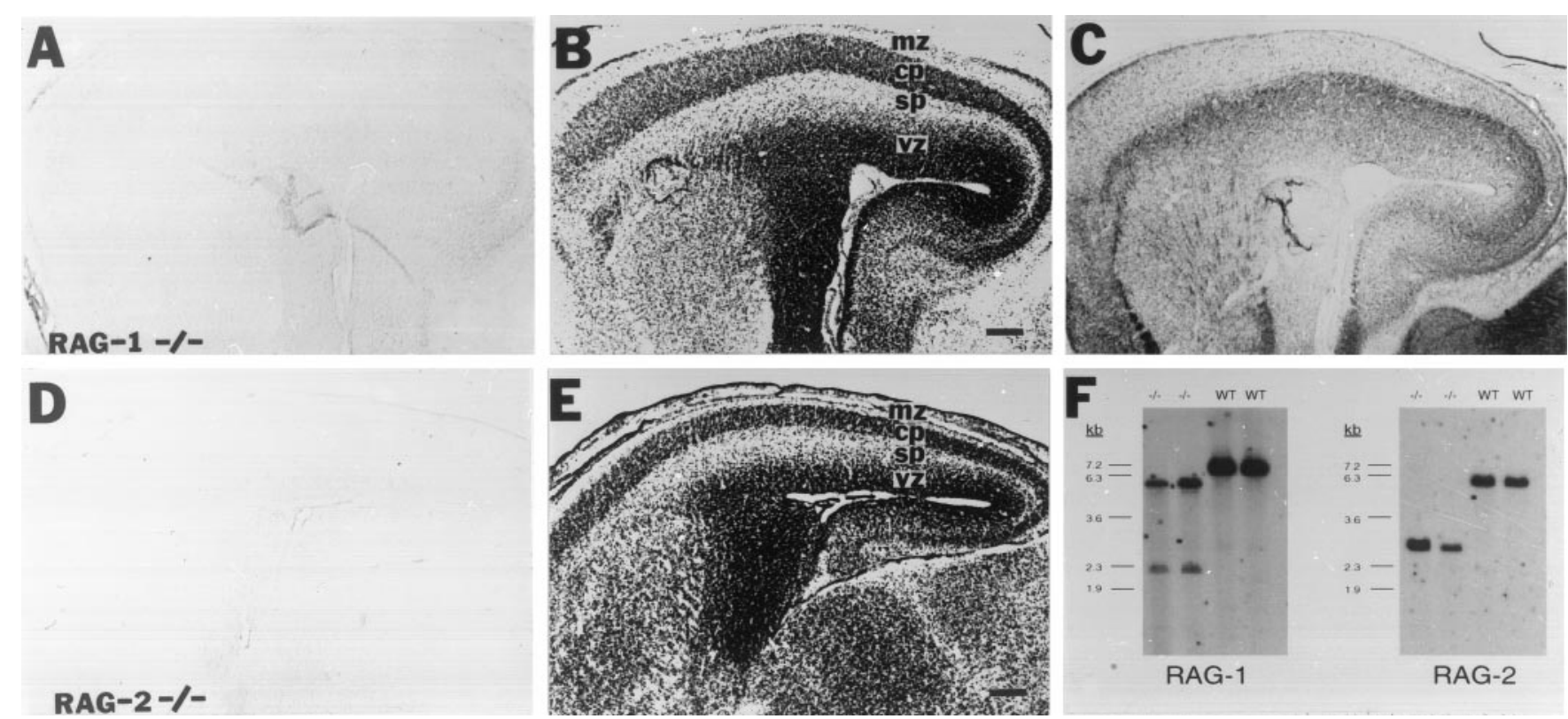

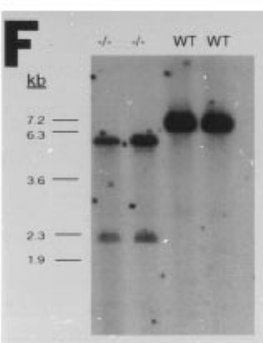

RAG-1

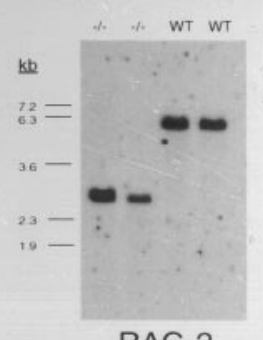

RAG-2

Figure 3. Ig-ir is absent from RAG-1 and RAG- $2-/-$ CNS. Adjacent sagittal sections through E16 RAG-1 $-/-(A-C)$ and E16 RAG-2 $-/-(D, E)$ cortex were stained with anti-mouse $\operatorname{IgG}$ antiserum $(A, D)$, cresyl violet $(B, E)$, or anti-synapsin $\mathrm{I}(C)$. Ig-ir seen in wild-type cortex is absent from RAG-1 $-/-$ cortex $(A)$, despite qualitatively normal cortical zones $(B$, cresyl violet-stained adjacent section). $C$, An adjacent RAG-1 -/ - section stained for synapsin I suggests that the absence of Ig-ir is not attributable to the absence of a subplate zone. The same blood vessel can be identified in $A$ and $C$. A similar result is obtained in E16 RAG-2 - - - cortex $(D, E)$. F, A representative Southern blot of genomic DNA using probes distinguishing RAG-1 (Mombaerts et al., 1992) or RAG-2 -/- (Shinkai et al., 1992) mice from wild type. $k b$, Kilobases; $m z$, marginal zone; $c p$, cortical plate; $s p$, subplate; $v z$, ventricular zone. Scale bar, $200 \mu \mathrm{m}$. Left indicates rostral; top, dorsal.

A
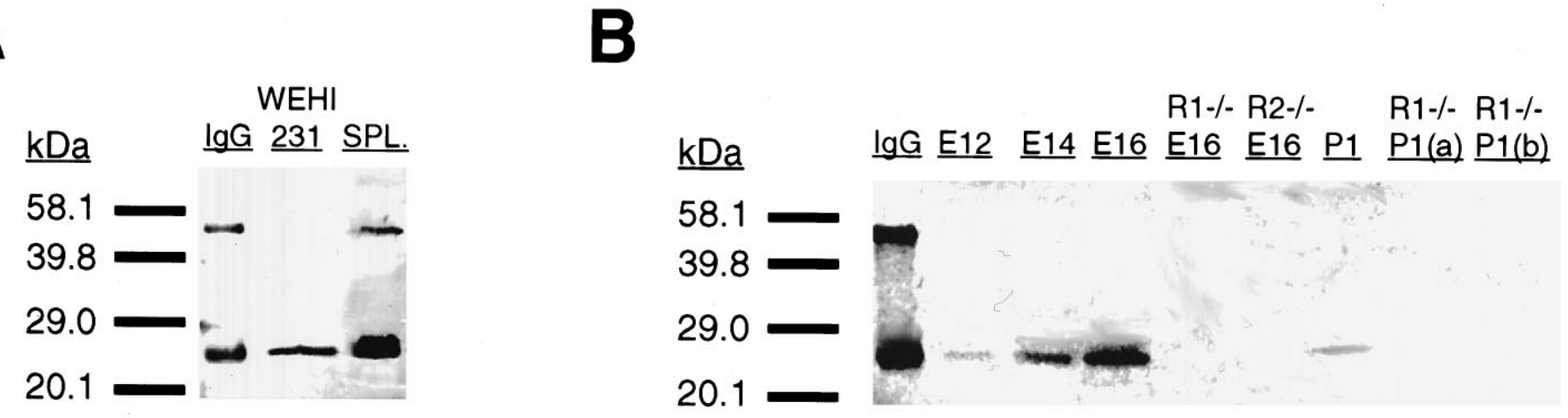

Synapsin

Figure 4. Western blot analysis of wild-type fetal brain detects a $25 \mathrm{kDa}$ light chain-like molecule. A, A Western blot of control protein samples indicates that the anti-IgG antiserum recognizes the expected Ig proteins in a purified mouse IgG preparation and in an adult spleen sample (SPL.): a $55 \mathrm{kDa}$ band corresponding to $\gamma$ heavy chain and a $25 \mathrm{kDa}$ band corresponding to $\kappa$ or $\lambda$ light chain. The B-cell line WEHI 231 produces $\kappa$ light chain, which is detected, and $\mu$ heavy chain, which is not detected by the anti-IgG antiserum. [The 55 and $25 \mathrm{kDa}$ bands are unequal in the spleen sample, because the antiserum recognizes light chains common to all Ig classes (IgM, IgA, IgD, IgE, and IgG) present in the spleen but only heavy chains of the $\gamma(\mathrm{G})$ class; these represent only a portion of all heavy chain proteins. In addition, light chain heterogeneity is responsible for the thickness of the $25 \mathrm{kDa}$ band in spleen and IgG samples compared with the monoclonal WEHI 231 band.] $B$, An immunoreactive band comigrating with light chain at $\sim 25 \mathrm{kDa}$ is clearly detected in wild-type brain samples at E12, E14, E16, and P1. No immunoreactive bands are detected in brain samples from E16 RAG-1 or RAG-2 -/- mice or in P1 brain samples from two independently derived RAG-1 - /- strains (denoted $a$ and $b$ ). A duplicate brain sample blot probed with anti-synapsin I is shown as a loading and transfer control (synapsin doublet appears as a single band because of gel concentration); comparisons can be made among different samples at the same age but not between ages. $k D a$, Kilodaltons.

\section{Ig light chain localization suggests developmental roles}

Light chain is present in the subplate and marginal zones of the fetal cerebral cortex, known sites of interactions between a variety of cellular elements including migrating neurons, radial glia, and afferent and efferent projections (Rakic, 1977; Chun and Shatz, 1988a,b; DeCarlos and O'Leary, 1992). The time course of light chain immunoreactivity also correlates with these events. Although the function of light chain in the cortex is unknown, its localization to the specialized environment of the subplate and marginal zones is consistent with the presence in these zones of other adhesive molecules such as fibronectin (Stewart and Pearl- 


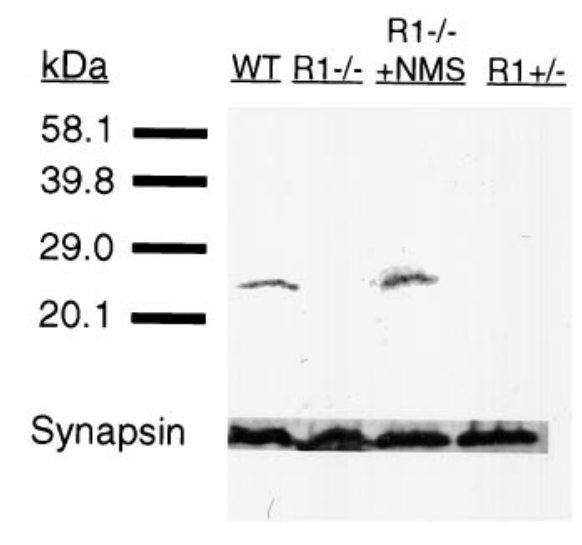

Figure 5. Wild-type Ig-ir is reconstituted in RAG-1 $-/-$ embryos by maternal injection with normal mouse serum. A Western blot of E16 brain samples from various mice was probed with anti-IgG antiserum $(A)$. Analysis of brain samples from E16 RAG-1 -/- mice derived from females injected at E13.5 with normal mouse serum (R1-/ - + NMS) illustrates reconstitution of the wild-type $25 \mathrm{kDa}$ Ig-immunoreactive band. No immunoreactive bands are detected, however, in brain samples from E16 RAG-1 +/- mice. As a loading and transfer control, a duplicate blot was probed with anti-synapsin I. $B$, A sagittal section through the cortex of an E16 RAG-1 - /- serum-treated mouse was stained with anti-IgG antiserum. In contrast to untreated RAG-1 -/- embryos (compare Fig. $3 A$ ), Ig-ir is present, although localization to the subplate and marginal zone is not as precise as in wild-type embryos (see Discussion). Arrows delineate the approximate borders of the subplate. $C$, A section through the hindbrain and spinal cord of the same mouse as in $B$, stained for $\operatorname{IgG}$ shows that wild-type Ig-ir is also restored in these regions. $m$, Medulla; $s c$, spinal cord. Scale bar, $200 \mu \mathrm{m}$.
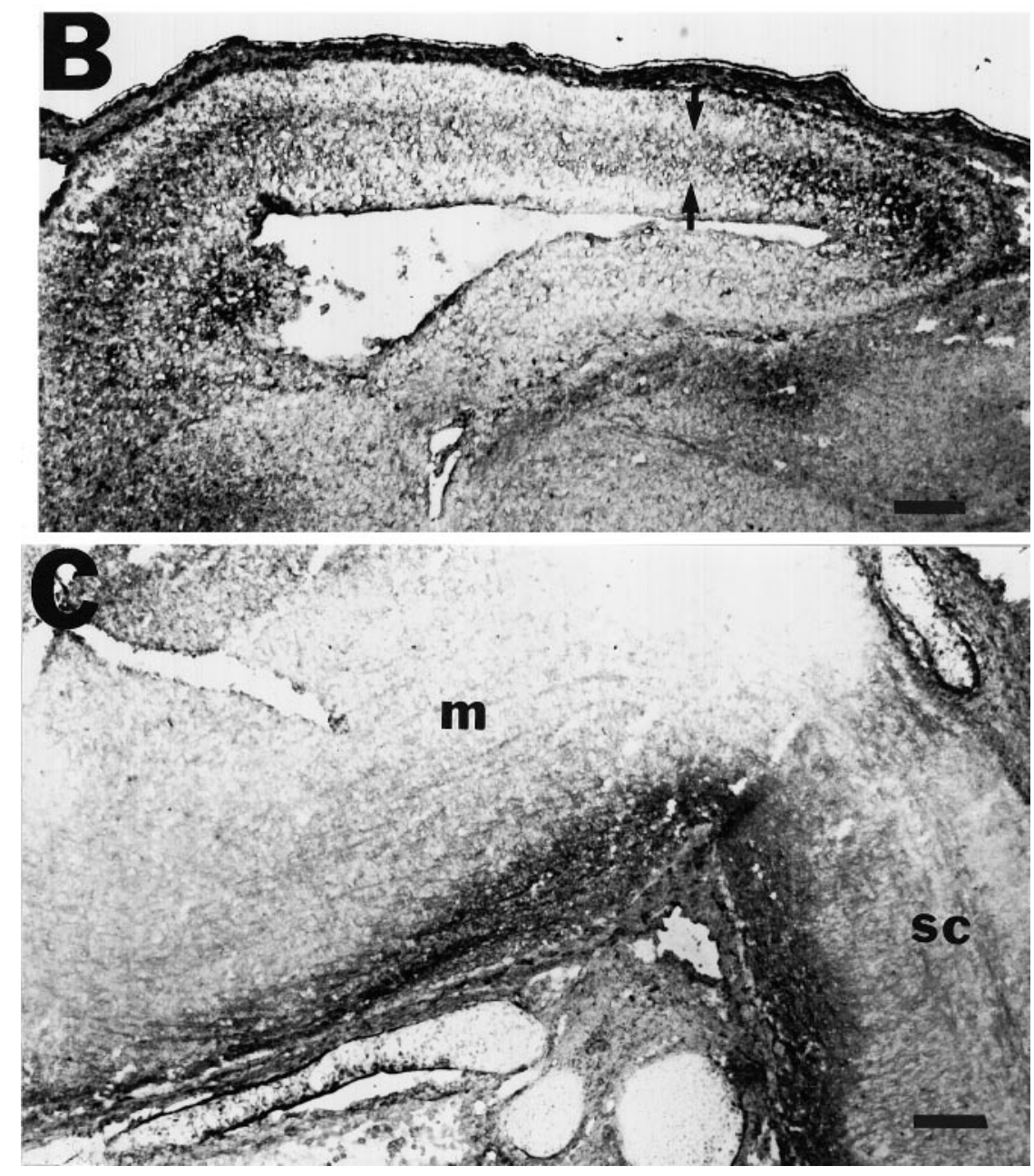

man, 1987; Chun and Shatz, 1988a), laminin (Hunter et al., 1992), and condroitin sulfate proteoglycans (Sheppard et al., 1991). The possible interactions between Ig light chain and these adhesion molecules warrant additional study.

Additional insight into the possible CNS function of light chain may be gained from examination of brain development in RAG $-/-$ mice. Initial reports of a normal nervous system in RAG-1 -/- mice (Mombaerts et al., 1992) were based solely on gross morphological appearances of cresyl violet-stained adult brain sections. Further, the $-/-$ mice examined were derived from heterozygous $(+/-)$ females (Mombaerts et al., 1992), which, having one copy of the RAG-1 gene, would have functional Ig transferred to the developing embryos. Therefore, the brain phenotypes reported for these animals may differ from those of mice bred from homozygous $(-/-)$ mothers. Despite normal gross morphology, subtle abnormalities may be present; in genetic null mutation studies of the neural IgSF molecules N-CAM and MAG, for example, very mild deficits are observed, despite their postulated important developmental roles (Tomasiewicz et al., 1993; Cremer et al., 1994; Montag et al., 1994). This could reflect genetic rescue of the phenotype by other IgSF members, which may substitute for absent molecules (Müller and Kypta, 1995). 
MAG-deficient mice, for example, show an upregulation of $\mathrm{N}-\mathrm{CAM}$ at sites normally expressing MAG (Montag et al., 1994). A similar upregulation of N-CAM, L1, or other molecules in the subplate of RAG-1 -/- mice could rescue a pronounced phenotype, despite the absence of light chain. The dynamics of IgSF expression in the RAG $-/-$ CNS deserve additional study.

An examination of CNS development in the absence of RAG expression is further complicated by the finding that RAG-1 transcripts are present throughout the fetal and postnatal CNS (Chun et al., 1991). Because the CNS light chain is maternally derived and dependent not only on RAG-1 but also on RAG-2, transcripts of which cannot reliably be detected in the CNS (Chun et al., 1991), it is unlikely to be affected by RAG-1 activity in the fetal CNS. This is not surprising, because any recombination events mediated by RAG- 1 in the absence of RAG-2, such as those that could occur in the CNS, are unlikely to be identical to the immunological $\mathrm{V}(\mathrm{D}) \mathrm{J}$ recombination produced synergistically by the two RAG genes (Schatz and Chun, 1992; Chun and Schatz, 1993). The role of RAG-1 in the CNS remains unknown.

\section{Ig light chain may provide a maternal influence on fetal CNS development}

A possible implication of our results is that the maternal immune system may contribute to fetal neural development in addition to its accepted roles in fetal passive immunity (Appleby and Catty, 1983). Precedent for a maternal molecular contribution to the development of the fetal CNS comes from reports that maternally derived melatonin can entrain the fetal suprachiasmatic nucleus to the circadian rhythm (Davis and Mannion, 1988). Additional studies of Ig light chain function in the fetal CNS should provide insights into its role in neural development and into the dynamics of maternal-fetal interactions during gestation.

\section{REFERENCES}

Appleby P, Catty D (1983) Transmission of immunoglobulin to foetal and neonatal mice. J Reprod Immunol 5:203-213.

Ausubel FM, Brent R, Kingston RE, Moore DD, Seidman JG, Smith JA, Struhl K (1994) Current protocols in molecular biology. New York: Wiley.

Berggård I, Edelman GM (1963) Normal counterparts to Bence-Jones proteins: free L polypeptide chains of human $\gamma$-globulin. Proc Natl Acad Sci USA 49:330-336.

Boulder Committee (1970) Embryonic vertebrate central nervous system: revised terminology. Anat Rec 166:257-261.

Chen J, Trounstine M, Kurahara C, Young F, Kuo C-C, Xu Y, Loring JF, Alt FW, Huszar D (1993) B cell development in mice that lack one or both immunoglobulin $\kappa$ light chain genes. EMBO J 12:821-830.

Chun J, Jaenisch R (1996) Clonal cell lines produced by infection of neocortical neuroblasts using multiple oncogenes transduced by retroviruses. Mol Cell Neurosci 7:304-321.

Chun JJM, Shatz CJ (1988a) A fibronectin-like molecule is present in the developing cat cerebral cortex and is correlated with subplate neurons. J Cell Biol 106:857-872.

Chun JJM, Shatz CJ (1988b) Redistribution of synaptic vesicle antigens is correlated with the disappearance of a transient synaptic zone in the developing cerebral cortex. Neuron 1:297-310.

Chun JJM, Shatz CJ (1989) Interstitial cells of the adult neocortical white matter are the remnant of the early generated subplate neuron population. J Comp Neurol 282:555-569.

Chun JJM, Schatz DG (1993) Recombination activating gene-1 (RAG-1) transcription in the mammalian CNS: implications and future directions. In: Restorative neurology (Cuello AC, ed), pp 283-295. Amsterdam: Elsevier.

Chun JJM, Nakamura MJ, Shatz CJ (1987) Transient cells of the developing mammalian telencephalon are peptide-immunoreactive neurons. Nature 325:617-620.

Chun JJM, Schatz DG, Oettinger MA, Jaenisch R, Baltimore D (1991) The recombination activating gene-1 (RAG-1) transcript is present in the murine central nervous system. Cell 64:189-200.
Chung W-W, Lagenaur CF, Yan Y, Lund JS (1991) Developmental expression of neural cell adhesion molecules in the mouse neocortex and olfactory bulb. J Comp Neurol 314:290-305.

Cooper EL, Nisbet-Brown E (1993) Developmental immunology. New York: Oxford UP.

Cremer H, Lange R, Christoph A, Plomann M, Vopper G, Roes J, Brown R, Baldwin S, Kraemer P, Scheff S, Barthels D, Rajewsky K, Wille W (1994) Inactivation of the N-CAM gene in mice results in size reduction of the olfactory bulb and deficits in spatial learning. Nature 367: 455-459.

Davis FC, Mannion J (1988) Entrainment of hamster pup circadian rhythms by prenatal melatonin injections to the mother. Am J Physiol 355:R439-R448.

DeCarlos JA, O’Leary DDM (1992) Growth and targeting of subplate axons and establishment of major cortical pathways. J Neurosci 12:1194-1211.

Dunn JA, Kirsch JD, Naegele JR (1995) Transient immunoglobulin-like molecules are present in the subplate zone and cerebral cortex during postnatal development. Cereb Cortex 5:494-505.

Dziegielewska KM, Reader M, Matthews N, Brown WM, Møllgard K, Saunders NR (1993) Synthesis of the foetal protein fetuin by early developing neurons in the immature neocortex. J Neurocytol 22:266-272.

Elovaara I, Seppalla I, Kinnunen E, Laaksovirta H (1991) Increased occurrence of free immunoglobulin light chains in cerebrospinal fluid and serum in human immunodeficiency virus-1 infection. J Neuroimmunol 35:65-77.

Fairén A, Smith-Fernńdez A, Marti E, DeDiego I, de la Rosa EJ (1992) A transient immunoglobulin-like reactivity in the developing cerebral cortex of rodents. NeuroReport 3:881-884.

Fushiki S, Schachner M (1986) Immunocytological localization of cell adhesion molecules L1 and NCAM and the shared carbohydrate epitope L2 during development of the mouse neocortex. Dev Brain Res 24:153-167.

Ghosh A, Antonini A, McConnell SK, Shatz CJ (1990) Requirement for subplate neurons in the formation of thalamocortical connections. Nature 347:179-181.

Henschel R, Wahle P (1994) The SP1 antigen in subplate neurons of the developing cat cortex is an immunoglobulin-like molecule. Eur J Neurosci 6:1239-1246.

Hunter DD, Llinás R, Ard M, Merlie JP, Sanes JR (1992) Expression of s-laminin and laminin in the developing rat central nervous system. J Comp Neurol 323:238-251.

Luskin MB, Shatz CJ (1985) Studies of the earliest-generated cells of the cat's visual cortex: cogeneration of subplate and marginal zones. J Neurosci 5:1062-1075.

McBlane JF, van Gent DC, Ramsden DA, Romeo C, Cuomo CA, Gellert M, Oettinger MA (1995) Cleavage at a V(D)J recombination signal requires only RAG1 and RAG2 proteins and occurs in two steps. Cell 83:387-395.

Møllgard K, Jacobsen M (1984) Immunohistochemical identification of some plasma proteins in human embryonic and fetal forebrain with particular reference to the development of the neocortex. Dev Brain Res 13:49-63.

Møllgard K, Dziegielewska KM, Saunders NR, Zakut H, Soreq H (1988) Synthesis and localization of plasma proteins in the developing human brain. Dev Biol 128:207-221.

Mombaerts P, Iacomini J, Johnson RS, Herrup K, Tonegawa S, Papaioannou VE (1992) RAG-1 deficient mice have no mature B and T lymphocytes. Cell 68:869-877.

Montag D, Giese KP, Bartsch U, Martini R, Lang Y, Bluthmann H, Karthigasan J, Kirschner DA, Wintergerst ES, Nave KA, Zielasek J, Toyka KV, Lipp H-P, Schachner M (1994) Mice deficient for the myelin-associated glycoprotein show subtle abnormalities in myelin. Neuron 13:229-246.

Müller U, Kypta R (1995) Molecular genetics of neuronal adhesion. Curr Opin Neurobiol 5:36-41.

Naegele JR, Barnstable CJ, Wahle PR (1991) Expression of a unique 56 $\mathrm{kDa}$ polypeptide by neurons in the subplate zone of the developing cerebral cortex. Proc Natl Acad Sci USA 88:330-334.

Parr EL, Parr MB (1985) Localization of immunoglobulins in the mouse uterus, embryo, and placenta during the second half of pregnancy. J Reprod Immunol 8:153-171.

Rakic P (1977) Prenatal development of the visual system in rhesus monkey. Philos Trans R Soc Lond [Biol] 278:245-260. 
Risau W, Hallmann R, Albrecht U (1986) Differentiation-dependent expression of proteins in brain endothelium during the development of the blood-brain barrier. Dev Biol 117:537-545.

Rudick RA, Peter DR, Bidlack JM, Knutson DQ (1985) Multiple sclerosis: free light chains in cerebrospinal fluid. Neurology 35:1443-1449.

Schatz DG, Chun JJM (1992) V(D)J recombination and the transgenic brain blues. New Biol 4:188-196.

Schatz DG, Oettinger MA, Schlissel MS (1992) V(D)J recombination: molecular biology and regulation. Annu Rev Immunol 10:359-383.

Shapiro AL, Scharff MD, Maizel Jr JV, Uhr JW (1966) Synthesis of excess light chains of gamma globulin by rabbit lymph node cells. Nature 211:243-245.

Sheppard AM, Hamilton SK, Pearlman AL (1991) Changes in the distribution of extracellular matrix components accompany early morphogenetic events of mammalian cortical development. J Neurosci 11:39283942.

Shinkai Y, Rathbun G, Lam L-P, Oltz EM, Stewart V, Mendelsohn M, Charron J, Datta M, Young F, Stall AM, Alt FW (1992) RAG-2deficient mice lack mature lymphocytes owing to inability to initiate $\mathrm{V}(\mathrm{D}) \mathrm{J}$ rearrangement. Cell 68:855-867.
Sølling K (1981) Free light chains of immunoglobulins. Scand J Clin Lab Invest 157[Suppl]:1-83.

Spanopoulou E, Roman CAJ, Corcoran LM, Schlissel MS, Silver DP, Nemazee D, Nussenzweig MC, Shinton SA, Hardy RR, Baltimore D (1994) Functional immunoglobulin transgenes guide ordered B-cell differentiation in Rag-1-deficient mice. Genes Dev 8:1030-1042.

Stewart GR, Pearlman AL (1987) Fibronectin-like immunoreactivity in the developing cerebral cortex. J Neurosci 7:3325-3333.

Tomasiewicz H, Ono K, Yee D, Thompson C, Goridis C, Rutishauser U, Magnuson T (1993) Genetic deletion of a neural cell adhesion molecule variant (N-CAM-180) produces distinct defects in the central nervous system. Neuron 11:1163-1174.

Tonegawa S (1983) Somatic generation of antibody diversity. Nature 302:575-581.

Woo TU, Beale JM, Finlay BL (1991) Dual fate of subplate neurons in a rodent. Cereb Cortex 1:433-443.

Wood JG, Martin S, Price DJ (1992) Evidence that the earliest generated cells of the murine cerebral cortex form a transient population in the subplate and marginal zone. Dev Brain Res 66:137-140. 